\title{
Komunikasi Antarpribadi Orang Tua dan Remaja yang Kecanduan Media Sosial di Tangerang
}

\author{
Elvita Laurensia Santoso, H.H. Daniel Tamburian \\ elvita.915160034@stu.untar.ac.id,danielt@fikom.untar.ac.id \\ Fakultas Ilmu Komunikasi Universitas Tarumanagara
}

\begin{abstract}
In this era of globalization, the use of the internet is growing day by day. The internet service application most commonly used by Indonesian people is social media. The increasing need for social media especially among teenagers has resulted in social media addiction in Indonesia. This research was made with the aim to find out the activities and patterns of interpersonal communication between parents and teenagers who are addicted to social media in Tangerang. Meanwhile, the theory that supports this research is interpersonal communication and new media. This research uses a descriptive qualitative approach. While the data collection methods used are by conducting interviews, observation, documentation, library research and online data search. The results show that interpersonal communication activities undertaken by parents and teenagers who are addicted to social media in Tangerang are often carried out through social media rather than direct communication. The messages exchanged are only in the form of daily conversations and are often one-way. This shows that interpersonal communication that occurs is not open and tends to experience interference. Meanwhile, the pattern of interpersonal communication most widely used is the equality pattern.
\end{abstract}

Keywords: interpersonal communication, parents, social media addiction, teenagers

\begin{abstract}
Abstrak
Di era globalisasi saat ini, penggunaan internet kian hari kian meningkat. Aplikasi layanan internet yang paling sering digunakan oleh masyarakat Indonesia adalah media sosial. Kebutuhan akan media sosial terutama di kalangan remaja mengakibatkan terjadinya media sosial adiktif di Indonesia. Penelitian ini dibuat dengan tujuan untuk mengetahui aktivitas dan pola komunikasi antarpribadi orang tua dan remaja yang kecanduan media sosial di Tangerang. Adapun, teori yang mendukung penelitian ini adalah komunikasi antarpribadi dan media baru. Penelitian ini menggunakan pendekatan kualitatif secara deskriptif. Sedangkan metode pengumpulan data yang digunakan yaitu dengan melakukan wawancara, observasi, dokumentasi, studi kepustakaan dan penelusuran data online. Hasil penelitian menunjukan bahwa aktivitas komunikasi antarpribadi yang dilakukan orang tua dan remaja yang kecanduan media sosial di Tangerang sering dilakukan melalui media sosial daripada komunikasi langsung. Pesan yang dipertukarkan juga berupa percakapan sehari-hari saja dan seringkali bersifat satu arah. Hal ini menunjukkan komunikasi antarpribadi yang terjadi tidak terbuka dan cenderung mengalami gangguan. Sementara itu, pola komunikasi antarpribadi yang paling banyak digunakan oleh orang tua dan remaja yang kecanduan media sosial di Tangerang adalah pola persamaan.
\end{abstract}

Kata Kunci: kecanduan media sosial, komunikasi antarpribadi, orang tua, remaja 


\section{Pendahuluan}

Era globalisasi membuat perkembangan teknologi saat ini semakin pesat. Seorang ahli bernama George Ritzer (2010, p.57), mengemukakan bahwa era globalisasi ditandai dengan adanya inovasi di bidang komunikasi. Inovasi tersebut mempermudah masyarakat untuk dapat berinteraksi dengan sesamanya. Salah satu contoh inovasi yang digunakan masyarakat adalah internet. Jaringan internet memungkinkan manusia berkomunikasi tanpa terbatas ruang dan waktu sehingga membuat manusia yang merupakan makhluk sosial semakin gencar menggunakan internet. Hal ini dibuktikan dari hasil survei data statistika yang dilakukan oleh APJII (Asosiasi Penyelenggara Jasa Internet Indonesia, 2017) menunjukkan bahwa pengguna internet di Indonesia semakin bertumbuh setiap tahunnya. Dan data terbaru (2018) menurut APJII, pengguna internet di tahun 2018 kembali mengalami peningkatan dari 143,26 (2017) hingga 171,17 juta jiwa. Hal ini menunjukkan bahwa kebutuhan manusia akan internet kian hari kian bertumbuh. APJII (2018) juga melakukan sebuah survei kepada 2.500 responden tentang aplikasi layanan internet yang paling sering digunakan. Hasil menunjukkan bahwa layanan chatting merupakan layanan yang paling banyak digunakan $(89,35 \%)$ diikuti dengan media sosial $(87,13 \%)$. Dapat disimpulkan bahwa penduduk Indonesia cenderung menggunakan internet untuk media sosial.

Kebutuhan dan penggunaan media sosial yang terus meningkat mengakibatkan terjadinya media sosial adiktif di Indonesia. Menurut dr. Siste (2018), adiktif atau kecanduan merupakan sebuah perilaku yang menekan untuk melakukan sesuatu secara terus menerus meskipun terdapat akibat yang negatif. Orang yang mengalami suatu kecanduan kehilangan beberapa kemampuan otaknya sehingga menimbulkan perilaku negatif (Sumber: Kementerian Kesehatan).

American Psychological Association (2012) menjelaskan bahwa ketergantungan tidak hanya disebabkan oleh zat-zat adiktif, namun suatu perilaku tertentu juga dapat dapat menyebabkan kecanduan, salah satunya adalah kegiatan dalam menggunakan media sosial (Sumber: American Psychological Association,). The Graphic, Visualization \& Usability Center, the Georgia Institute of Technology (2011) menetapkan indikator seseorang dapat dikatakan sebagai social media addiction pada golongan berat yaitu 6 jam/hari (Sumber: Georgia Tech).

Dikarenakan kejadian ini terus bermunculan mendorong peneliti untuk mengetahui lebih lanjut mengenai media sosial adiktif khususnya di kalangan remaja (usia 15-19 tahun) karena menurut APJII 91\% penggunaan internet tahun 2018 didominasi oleh remaja usia 15-19 tahun. Dan menurut Kepala Pusat Data dan Informasi Ketenagakerjaan, Suhartono (2018), sebesar 90,61\% anak muda menggunakan internet untuk bermedia sosial. Oleh karena itu, media sosial adiktif ini seringkali terjadi di kalangan remaja, khususnya karena remaja saat ini merupakan generasi pertama dikala terjadinya perkembangan media sosial. Sumber data lain dari Badan Pusat Statistik (2018) menunjukan bahwa generasi muda usia 15-19 tahun saat ini mendominasi demografi di Indonesia. Terbukti dari kelompok 15-19 tahun mencapai persentase $8,32 \%$ atau dapat dikatakan kelompok tersebut meraih predikat sebagai milenial terbanyak di Indonesia. Dominasi tersebut juga terlihat dari beberapa bidang kehidupan, seperti menurut survei yang dilakukan oleh Lembaga Ilmu Pengetahuan Indonesia (2018) 40\% suara pemilihan umum 2019 didominasi oleh kaum milenial dan contoh lainnya yakni dominasi remaja pada media sosial. 
Menurut Tamburian (2017), media baru dapat mengubah norma-norma interaksi sosial sehingga perbedaan antara online dan offline (tatap muka antarpribadi) signifikan kabur yang dapat meminimalkan perbedaan bahasa antara keduanya. Hal ini sangat disayangkan karena jika dilihat dari tujuan komunikasi antarpribadi yang dikatakan oleh DeVito (2010), yakni untuk menemukan diri, membangun hubungan, mempengaruhi sikap dan menghibur diri; komunikasi antarpribadi dirasa sangat penting. Khususnya antara orang tua dan anak dikarenakan menurut Rustina (2014), keluarga merupakan kelompok primer pertama yang paling penting sehingga perlu dilakukan komunikasi yang baik antara remaja dan orang tua agar tujuan komunikasi antarpribadi tercapai.

Aspek komunikasi antarpribadi yang akan dikaji lebih lanjut dalam penelitian ini adalah pola dan aktivitas komunikasi antarpribadi antara orang tua dan remaja yang kecanduan media sosial. Adapun, alasan peneliti tertarik untuk meneliti di Tangerang dikarenakan berdasarkan data yang diungkapkan oleh Badan Pusat Statistik (2018), $80,45 \%$ atau hampir seluruh masyarakat Tangerang menggunakan internet untuk bermedia sosial (Sumber: bantenhits.com) Hal ini menunjukan bahwa aktivitas penggunaan media sosial di Tangerang sangatlah tinggi.

Berdasarkan uraian latar belakang diatas dan mengingat pentingnya komunikasi antarpribadi orang tua dan anak peneliti tertarik untuk melakukan penelitian lebih lanjut mengenai "Komunikasi Antarpribadi Orang Tua dan Remaja yang Kecanduan Media Sosial di Tangerang".

Dalam penelitian ini, peneliti menggunakan teori komunikasi antarpribadi dan media baru. Definisi komunikasi antarpribadi menurut Joseph A. DeVito (2016: 26), adalah interaksi secara verbal dan nonverbal antara dua atau lebih orang yang saling bergantung. Sedangkan, media baru menurut Liliweri (2014: 284) merupakan kemampuan media yang dengan dukungan perangkat digital dapat mengakses konten kapan saja, di mana saja sehingga memberi kesempatan bagi siapa saja untuk berpartisipasi secara aktif, interaktif dan kreatif terhadap pesan. Pada teori komunikasi antarpribadi, peneliti membahas lebih dalam mengenai definisi komunikasi antarpribadi (DeVito, 2016), komunikasi verbal (DeVito, 2016) dan

nonverbal (DeVito, 2016), elemen-elemen komunikasi antar pribadi (DeVito, 2016), prinsip komunikasi antarpribadi (Liliweri, 2014), karakteristik komunikasi antarpribadi (DeVito, 2010), hubungan antar pribadi (DeVito, 2010), komunikasi antarpribadi dalam keluarga (DeVito, 2016). Sementara itu pada teori media baru, peneliti membahas mengenai definisi media baru (Liliweri, 2014), definisi media sosial (Liliweri, 2014), karakteristik media sosial (Rulli Nasrullah, 2017), jenis-jenis media sosial (Rulli Nasrullah, 2017) dan teori media sosial adiktif (Tamburian, 2017).

\section{Rumusan Masalah}

"Bagaimana komunikasi antarpribadi antara orang tua dan remaja (usia 15-19 tahun) yang kecanduan media sosial di Tangerang?

\section{Tujuan Penelitian}

a. Untuk mengetahui aktivitas komunikasi antarpribadi antara orang tua dan remaja (usia 15-19 tahun) yang kecanduan media sosial di Tangerang.

b. Untuk mengetahui pola komunikasi antarpribadi orang tua dan remaja (usia 15-19 tahun) yang kecanduan media sosial di Tangerang 


\section{Metode Penelitian}

Pada penelitian ini, peneliti menggunakan metode penelitian kualitatif secara deskriptif. Pendekatan kualitatif merupakan proses eksplorasi dan memahami makna perilaku individu atau kelompok, menggambarkan masalah sosial dan kemanusiaan (Sugiyono, 2017). Sementara itu, metode deskriptif merupakan salah satu metode penelitian yang tujuannya untuk menyajikan gambaran lengkap yang dimaksudkan untuk eksplorasi dan klarifikasi mengenai suatu fenomena atau kenyataan sosial (Bungin, 2011). Adapun, dalam memilih subyek penelitian, peneliti menggunakan teknik purposive sampling. Menurut Sugiyono (2014) purposive sampling merupakan teknik pengambilan sumber data dengan kriteria tertentu. Untuk itu, dalam penelitian ini peneliti memilih informan berdasarkan kriteria yang telah ditentukan peneliti, yakni: usia 15-19 tahun dan orang tuanya, kecanduan media sosial kurang lebih satu tahun yang ditemukan peneliti melalui hasil observasi, domisili di Tangerang dan tinggal bersama orang tua. Sementara itu, kriteria orang ketiga yang dipilih peneliti adalah tinggal bersama atau dekat dengan informan. Berdasarkan kriteria di atas informan yang dipilih peneliti adalah:

a. Informan 1 : Irvandy (Usia 19 tahun) Bapak Tjen Sun Phin,Orang ketiga : Hansen Mulia (Teman Dekat Irvandy)

b. Informan 2 : Adrianne Dewi Victoria (Usia 17 tahun) dan orang tuanya (Ibu Merlina Surjana), Orang ketiga: Otniel Eliezer Manurung (Paman Dewi)

c. Informan 3 : Cecilia Miracle (Usia 16 tahun) dan orang tuanya (Ibu Alin Miracle), Orang ketiga : Berlian (Teman Dekat Cecil)

d. Informan 4 : Joanne Emanuela (Usia 15 tahun) dan orang tuanya (Ibu Evy Octavia), Orang ketiga: Diana (Kakak Sepupu Joanne)

e. Informan 5 : Irvan Samsi (Usia 18 tahun) dan orang tuanya (Bapak Samsi dan Ibu Devina), Orang ketiga : Ivana (Kakak Kandung Irvan)

f. Informan 6 : Ignasius Oscarino (Usia 19 tahun) dan orang tuanya (Bapak Jozef Setia Irianto), Orang ketiga : Agatha Christy Adriani (Kakak Kandung Oscar)

Alasan peneliti memilih 6 informan yang berupa remaja yang kecanduan media sosial, orang tuanya dan orang ketiga adalah karena peneliti merasa keenam informan tersebut sudah mampu memberikan informasi secara maksimum sesuai dengan yang peneliti butuhkan. Hal ini juga sesuai dengan yang disampaikan Idrus (2009) bahwa penelitian kualitatif tidak didasarkan pada perhitungan statistik ataupun jumlah tetapi pada kualitas informan yang mampu menjawab penelitian. Sementara itu, objek dalam penelitian ini adalah komunikasi antarpribadi orang tua dan remaja (usia 15-19 tahun) yang kecanduan media sosial. Metode pengumpulan data dalam penelitian ini adalah wawancara secara mendalam kepada 6 orang remaja beserta orang tuanya dan orang ketiga, observasi, dokumentasi, studi kepustakaan dan penelusuran data online. Selain itu, teknik analisis data dalam penelitian ini adalah dengan mengumpulkan, reduksi, penyajian data dan penarikan kesimpulan. Untuk membuktikan kebenaran dari penelitian ini atau untuk melakukan teknik keabsahan data, peneliti melakukan triangulasi secara sumber, metode dan teori. 


\section{Hasil Temuan dan Diskusi}

\section{Media Sosial Adiktif di Kalangan Remaja Tangerang}

Dari hasil wawancara dan observasi yang dilakukan peneliti ditemukan bahwa para remaja yang kecanduan media sosial di Tangerang menghabiskan waktu rata-rata lebih dari $7 \mathrm{jam} / \mathrm{hari}$ hal ini sejalan dengan penelitian yang dilakukan oleh Georgia Tech (2011). Sementara itu, rentang waktu para informan dalam mengenal media sosial cukup bervariasi. Informan 1 dan 3 telah mengenal sosial selama 4-5 tahun, informan 2, 4 dan 5 mengenal media sosial selama 6-7 tahun sedangkan narasumber 6 yang memiliki keluarga yang cenderung aktif di media sosial menghasilkannya mengenal dunia media sosial terlebih dahulu. Informan 6 telah menggunakan media sosial selama kurang lebih 7-9 tahun.

Di sisi lain, faktor yang mendasari para informan dalam bermain media sosial adalah faktor internal (hiburan), faktor kepentingan sosial (bersosialisasi), faktor eksternal (mencari informasi) dan faktor situasional (sebagai pelarian). Dari hasil temuan, ditemukan bahwa faktor yang paling banyak mendorong keenam narasumber untuk bermain media sosial adalah faktor internal, keenam narasumber sama-sama menggunakan media sosial sebagai sarana hiburan. Dan temuan baru yang didapatkan peneliti saat melakukan observasi adalah ditemukan alasan lain yang mendorong beberapa informan khususnya informan 3 dan 4 untuk menggunakan media sosial adalah sebagai sarana pengungkapan diri. Di sisi lain, informan mengungkapkan media sosial yang paling sering digunakan adalah media berbagi (Youtube dan Instagram) dan jejaring sosial (Whatsapp, LINE, Facebook). Temuan lain yang juga ditemukan adalah media sosial adiktif saat ini tidak hanya terjadi pada remaja tetapi juga mulai terjadi pada beberapa orang tua.

\section{Aktivitas Komunikasi Antarpribadi Orang Tua dan Remaja yang Kecanduan Media Sosial di Tangerang}

Aktivitas komunikasi antarpribadi mencakup komunikasi verbal dan nonverbal. Dilihat dari hasil observasi dan wawancara yang dilakukan oleh peneliti, komunikasi verbal yang dilakukan oleh orang tua dan remaja yang kecanduan media sosial digantikan melalui media sosial. Terbukti dari enam keluarga informan, tiga keluarga (1, 3 dan 6) menggantikan komunikasi langsung menjadi komunikasi melalui media sosial. Jika dilihat dari komunikasi nonverbal, ditemukan bahwa komunikasi yang terjadi antara orang tua dan anak yang kecanduan media sosial cenderung bersifat satu arah sehingga pesan nonverbal tidak dapat disampaikan dengan baik atau bahkan cenderung tidak tersampaikan. Dalam kasus ini, komunikasi nonverbal berupa parabahasa sangat berperan sedangkan bagi keluarga yang orang tuanya juga suka bermain media sosial, tidak terdapat pesan nonverbal yang diberikan karena komunikasi langsung digantikan dengan media sosial. Pesan nonverbal kadang kala hanya digantikan dengan sticker atau emoticon.

Pada sebuah aktivitas komunikasi antarpribadi orang tua dan anak terdapat elemenelemen di dalamnya, yakni :

1. Sumber-penerima, dalam penelitian ini berupa orang tua dan anak yang kecanduan media sosial

2. Pesan, pesan yang disampaikan orang tua dan anak yang kecanduan media sosial cenderung hanya percakapan sehari-hari aja.

3. Encoding-decoding, Proses encoding yang umumnya dilakukan oleh keenam informan adalah dengan berbicara secara langsung atau sesekali digantikan 
oleh media sosial. Sedangkan proses decoding sering kali mengalami gangguan dikarenakan dalam proses mendengar, pesan yang disampaikan tidak terdengar dengan baik karena terlalu fokus dengan media sosial.

4. Media, beberapa orang tua yang anaknya kecanduan media sosial mulai menggantikan komunikasi langsung dengan media sosial. Beberapa orang tua masih melakukan komunikasi langsung namun intensitasnya sangat jarang.

5. Gangguan, komunikasi antarpribadi orang tua dan anak yang kecanduan media sosial cenderung terganggu.

6. Umpan balik, umpan balik yang diberikan anak cenderung negatif, tertunda atau bahkan kadang tidak terdapat umpan balik sama sekali. Sementara, beberapa informan mengaku tidak melakukan komunikasi dengan orang tuanya saat bermain media sosial sehingga tidak ada umpan balik bahkan pesan yang dipertukarkan.

7. Konteks, remaja yang mengalami kecanduan media sosial di Tangerang cenderung tidak memahami konteks komunikasi, Dapat dilihat, anak cenderung diam jika diajak komunikasi. Padahal jika anak tersebut memahami dengan siapa dia bicara (orang tua) maka harusnya menunjukkan respon atau umpan balik yang positif. Hal ini juga mulai terjadi kepada beberapa orang tua yang juga suka memainkan media sosial.

8. Etika, para informan cenderung tidak memahami etika komunikasi dengan bertindak cuek dan tidak menghargai pesan yang diberikan orang tuanya.

Selain elemen, aktivitas komunikasi antarpribadi yang baik juga dinilai dari karakteristiknya. Jika dilihat dari karakteristiknya, komunikasi antarpribadi orang tua dan remaja yang kecanduan media sosial cenderung belum berjalan baik karena jika dikaitkan dengan teori karakteristik komunikasi antarpribadi, orang tua dan para informan masih belum terbuka bahkan cenderung tertutup dilihat dari kedalaman pesan yang disampaikan. Selain tidak terbuka, komunikasi yang terjadi juga tidak terdapat empati dapat dilihat dari para informan yang tidak memahami perasaan orang tuanya yang mengaku kecewa, dan marah. Sementara itu, jika dilihat dari sikap mendukung, keenam informan tidak memiliki sikap mendukung kepada orang tuanya dilihat dari mereka yang diam saja ketika diajak komunikasi dengan orang tuanya. Hal ini berbalik terbalik dengan orang tua para informan yang tetap mendukung anaknya yang suka bermain media sosial dengan tidak memberikan peraturan yang terlalu ketat agar anak tidak menjadi tertekan. Di lain sisi, jika dilihat dari karakteristik yang berupa sikap positif menunjukkan bahwa keenam informan tidak memiliki sikap positif ke orang tuanya, lima dari enam informan cenderung merasa terganggu ketika orang tuanya ingin mengajak mereka untuk berkomunikasi. Sementara itu salah satu informan (informan 1) merasa tidak merasa terganggu karena orang tuanya tidak membuka komunikasi saat informan 1 sedang bermain media sosial sedangkan orang tua para informan justru memiliki sikap positif kepada anaknya dengan tetap berpikir positif dan percaya kepada anaknya bahwa anaknya juga butuh media sosial dan mampu bertanggung jawab walaupun orang tuanya menyadari bahwa kesukaan mereka akan media sosial sudah pada tahap berlebihan. Sementara itu, jika dilihat dari sisi kesetaraan, komunikasi yang terjadi antara orang tua dan keenam informan masih belum berjalan setara. Dilihat dari komunikasi yang masih sering bersifat satu arah (orang tua berbicara, anak diam) atau sebaliknya pada kasus orang tua yang suka bermain media sosial sedangkan dari sisi orang tua berusaha bersikap setara dengan tetap menghargai pendapat anaknya bahwa mereka juga butuh media sosial walaupun 
anaknya berumur lebih muda (sering kali dianggap tidak kredibel). Orang tua yang berusaha bersikap setara ini terlihat di keluarga informan 1, 4, 5 dan 6 .

\section{Pola Komunikasi Antarpribadi Orang Tua dan Remaja yang Kecanduan Media Sosial di Tangerang}

Pola komunikasi yang paling sering digunakan oleh orang tua dan remaja yang kecanduan media sosial adalah pola kesetaraan, khususnya pada informan 4,5 dan.6. Keluarga ketiga informan tersebut cenderung bersikap bebas dan terbuka. Setiap orang dapat menyampaikan pendapatnya. Walaupun komunikasinya terbuka namun dikarenakan kesibukan masing-masing orang tua dan terlalu bebasnya aturan membuat anak merasa tidak dikekang sehingga membuat mereka dengan bebasnya bermain media sosial walaupun saat sedang berkomunikasi dengan orang tuanya. Selain itu, karena kehadiran media sosial dan kesibukan orang tua membuat komunikasi cenderung jarang terjadi.

Gambar 1. Pola Persamaan

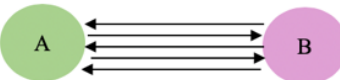

Sumber: DeVito (2016)

Sementara itu, pola komunikasi terpisah-seimbang diterapkan oleh keluarga informan 1 Orang tua informan 1 membagi pesan berdasarkan kredibilitas masingmasing. Misalnya, anaknya memegang kendali di bidang media sosial sementara orang tua di bidang bisnis.

Gambar 2. Pola Terpisah-Seimbang

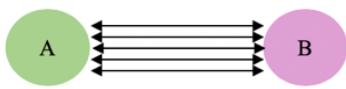

Sumber: DeVito (2016)

Selain itu, di pola terpisah-tidak seimbang diterapkan oleh keluarga informan 3. Dalam komunikasi keluarga informan 3, terdapat salah satu anggota keluarga yang lebih dominan, yakni informan 3 sendiri. Hal ini juga diakui oleh teman dekat informan 3 .

Gambar 3. Pola Terpisah-Tidak Seimbang

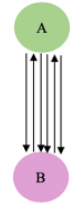

Sumber: DeVito (2016)

Pada pola terakhir yakni pola monopoli, diterapkan oleh keluarga informan 2 . Ayah dari informan 2 sendiri seringkali membuat tuntutan membuat informan 2 takut berbicara dengan ayahnya dan menghabiskan waktunya di media sosial. 
Gambar 4. Pola Monopoli

Sumber: DeVito (2016)

Dalam diskusi, disimpulkan bahwa hasil penelitian sejalan dengan penelitianpenelitian yang dilakukan sebelumnya. Namun, perbedaannya, penelitian terdahulu menggunakan pendekatan kuantitatif sehingga tidak ditelaah secara dalam bagaimana komunikasi antarpribadi yang terjadi. Sementara itu, kaitan hasil penelitian dengan kajian ilmu komunikasi secara praktik adalah, untuk dapat melakukan komunikasi antarpribadi yang baik diperlukan komunikasi yang terbuka dan aturan yang tegas namun tetap fleksibel atau dapat dikatakan sebaiknya para orang tua yang memiliki remaja yang kecanduan dapat tetap menggunakan pola keluarga komunikasi konsensual namun diimbangi dengan tipe keluarga konsensual (komunikasi sering dan terbuka, aturan (kesesuaian) yang tegas).

\section{Simpulan}

Berdasarkan hasil penelitian dapat disimpulkan aktivitas komunikasi antarpribadi orang tua dan remaja sering dilakukan melalui media sosial sebagai pengganti komunikasi langsung khususnya pada anak yang orang tuanya juga suka bermain media sosial. Sementara itu, pesan yang disampaikan juga terbatas hanya seputar percakapan sehari-hari saja. Hal ini menunjukkan bahwa komunikasi antarpribadi yang terjadi antara orang tua dan remaja yang kecanduan media sosial tidak terbuka dan cenderung mengalami gangguan karena seringkali komunikasi antarpribadi yang terjadi bersifat satu arah. Sementara itu, pola komunikasi yang paling banyak digunakan adalah pola persamaan. Dapat disimpulkan pula bahwa orang tua yang cenderung sibuk (bekerja ataupun bermain media sosial) memiliki komunikasi antarpribadi yang jarang dan tidak terbuka dengan anaknya, sementara itu orang tua yang terlalu otoriter membuat komunikasi menjadi tidak ada karena anak takut berbicara dengan orang tua. Aturan yang tidak tegas juga membuat anak menjadi tidak takut dan tetap fokus kepada media sosial sehingga kecanduan media sosial terus terjadi.

\section{Ucapan Terima Kasih}

Peneliti ingin mengucapkan terima kasih kepada orang tua dan kakak penulis yang telah memberi dukungan tiada henti, para dosen terkhusus dosen pembimbing yang telah membina peneliti, para informan yang telah membantu kelancaran penelitian dan kepada teman-teman Fakultas Ilmu Komunikasi 2016 serta sahabatsahabat peneliti yang tidak dapat disebutkan satu per satu.

\section{Daftar Pustaka}

DeVito, Joseph. A. (2010). Komunikasi Antarmanusia (ed. 5). Tangerang Selatan: Karisma Publishing Group. 
Elvita Laurensia Santoso, H.H. Daniel Tamburian: Komunikasi Antarpribadi Orang Tua dan Remaja yang Kecanduan Media Sosial di Tangerang

DeVito, Joseph. A. (2016). The Interpersonal Communication Book (14th Ed.). England: Pearson Education.

Ritzer, George. (2010). The Globalization of Nothing. Yogyakarta: Universitas Atmajaya. Sugiyono. (2014). Metode Penelitian Kuantitatif, Kualitatif dan R\&D (ed.1, cet.20). Bandung: Alfabeta, CV.

Sugiyono. (2017). Metode Penelitian Kualitatif (ed. 3, cet.1). Bandung: Alfabeta, CV.

Tamburian, H.H. Daniel. (2017). Konstruksi Identitas Diri Remaja Pengguna Media Facebook di Kota Bogor. Laporan Penelitian Fakultas Ilmu Komunikasi Universitas Tarumanagara.

http://www.depkes.go.id/article/view/18070600008/bijak-gunakan-smartphone-agartidak-ketergantungan.html)

https://www.apa.org

https://smartech.gatech.edu/handle/1853/3723

https://bantenhits.com/2018/03/04/8045 